\title{
Respiratory Syncytial Virus Infection in Elderly Adults
}

\author{
Ann R. Falsey and Edward E. Walsh \\ Department of Medicine, University of Rochester School of Medicine and Dentistry, and the \\ Department of Medicine, Rochester General Hospital, Rochester, New York, USA
}

\section{Contents}

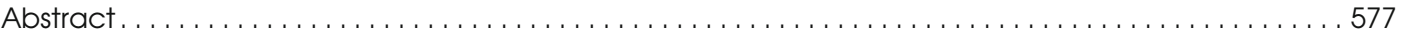

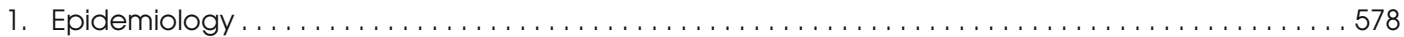

1.1 Elderly in Long-Term Care Facilities. . . . . . . . . . . . . . . . . . . . . . . . . . . . . . . . . . . . . . . 578

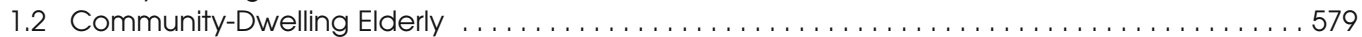

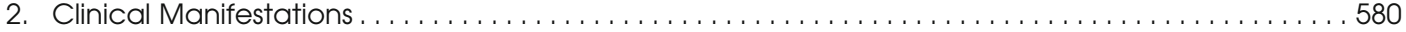

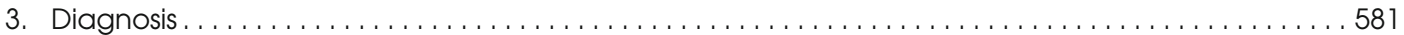

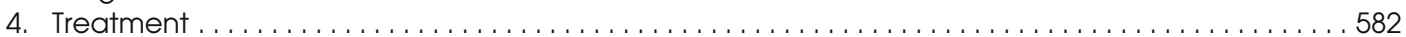

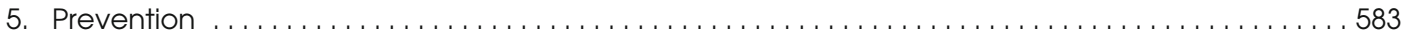

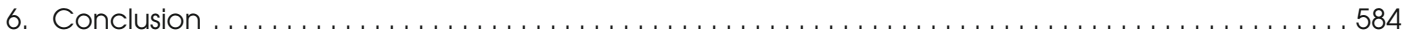

Respiratory syncytial virus (RSV) infection is now recognised as a significant problem in elderly adults. Epidemiological evidence indicates the impact of RSV in older adults may be similar to nonpandemic influenza, both in the community and in long-term care facilities. Attack rates in nursing homes are approximately $5-10 \%$ per year with significant rates of pneumonia (10-20\%) and death $(2-5 \%)$. Estimates using US healthcare databases and viral surveillance results over a 9-year period indicate that RSV infection causes approximately 10000 all-cause deaths annually among persons $>64$ years of age. In contrast, influenza A accounted for approximately 37000 yearly deaths in the same age group. The clinical features of RSV infection may be difficult to distinguish from those of influenza but include nasal congestion, cough, wheezing and low-grade fever. Older persons with underlying heart and lung disease and immunocompromised patients are at highest risk for RSV infection-related pneumonia and death. Diagnosis of RSV infection in adults is difficult because viral culture and antigen detection are insensitive, presumably because of low viral titres. The combination of serology and reverse transcriptase polymerase chain reaction assay offers the best sensitivity and specificity for the diagnosis of RSV but unfortunately these techniques are not widely available; consequently, most adult RSV disease goes unrecognised. Although treatment of RSV infection in the elderly is largely supportive, early therapy with ribavirin and intravenous $\gamma$-globulin improves survival in immunocompromised persons. An effective RSV vaccine has not yet been developed. Therefore, prevention of RSV is limited to standard infection control practices, such as hand washing and the use of gowns and gloves. 
Human respiratory syncytial virus (RSV) is an enveloped, single-stranded, negative sense RNA virus. It is a member of the Paramyxoviridae family and is classified in the genus Pneumovirus. ${ }^{[1]} \mathrm{RSV}$ isolates can be divided into two major groups, A and $\mathrm{B}$, based upon antigenic and genetic analysis. ${ }^{[2-4]}$ Other members of the paramyxovirus family that have similar structural and genetic organisation include the closely related parainfluenza viruses and the recently described human metapneumovirus. ${ }^{[5]}$ Together, these viruses cause a substantial proportion of severe respiratory illnesses in paediatric populations, but RSV is recognised as the most important of these pathogens. Bronchiolitis, manifested by wheezing and hypoxia, is the characteristic clinical syndrome caused by RSV in infants and results in approximately 100000 paediatric hospitalisations annually in the US. ${ }^{[6]}$ Shortly after its initial identification in 1956, RSV infection was reported in adults and it is now firmly established that reinfections occur frequently throughout life, and into old age. ${ }^{[7,8]}$ Although most reinfections are relatively mild, the frail elderly, those with underlying high-risk cardiopulmonary diseases, and the severely immunosuppressed are at significant risk of severe respiratory illness. ${ }^{[8,9]}$ Failure of RSV infection to induce solid immunity is a major impediment to the development of an efficacious RSV vaccine for both infants and adults.

RSV predictably circulates each winter in temperate climates and during the rainy season in the tropics. Yearly epidemics generally last for 4-5 months, typically beginning in autumn and lasting until late winter or early spring. Although minor variations in viral activity are seen from year to year, the epidemic curve for RSV is fairly constant, unlike the more dramatic paroxysmal activity of influenza virus. After an incubation period of 3-5 days, symptomatic respiratory illness develops in the majority of persons with either primary or repeat infections. In adults inoculated by experimental challenge, $\mathrm{RSV}$ is shed at relatively low titre $\left(\sim 10^{2-3}\right.$ plaque forming units $[\mathrm{pfu}] / \mathrm{mL}$ of secretions) for 3-6 days, in contrast with infants with natural infection who shed for a considerably longer time and at higher titre (10-14 days at $\left.\sim 10^{5-6} \mathrm{pfu} / \mathrm{mL}\right) \cdot{ }^{[10,11]}$ Although quantitative virus shedding has not been measured in older adults, it is likely that titres are generally low since diagnosis by viral culture or antigen detection is difficult. ${ }^{[12]}$

\section{Epidemiology}

\subsection{Elderly in Long-Term Care Facilities}

The first reports of RSV infections in nursing home residents appeared in the 1970s, and since then there have been at least 20 published accounts of RSV in long-term care facilities. ${ }^{[13-30]}$ Some reports described RSV outbreaks involving between 8 and 52 residents, with overall attack rates ranging from $12 \%$ to $89 \%$. In 11 prospective surveillance studies, attack rates were considerably lower, ranging from $1.4 \%$ to $40 \%$. Much of this inconsistency can be attributed to the use of relatively insensitive serological assays and/or culture for diagnosis, and to the fact that case definitions varied substantially. In the prospective studies, pneumonia rates were $0-33 \%$ and death occurred in $0-5 \%$. In one prospective winter surveillance study conducted in a large Rochester, NY, USA nursing home, RSV infection was documented in 40 persons by culture and sensitive enzyme immunoassay (EIA). ${ }^{[17]}$ The overall attack rate was $7 \%$ and RSV was identified as the cause of $27 \%$ of the illnesses. Although the presence of both group A and B viruses indicated at least two separate virus introductions, the room locations of infected patients and the clustering of RSV strain types strongly suggested nosocomial transmission by healthcare workers. In most of the outbreaks reported, RSV circulated simultaneously with other viruses, most notably influenza A virus, thus highlighting the error of attributing all respiratory tract illnesses to influenza when a few cases are identified.

As noted, the composite of nursing home reports suggest that RSV attack rates are quite variable and the overall scope of the problem is thus difficult to estimate. In order to obtain a broader view of RSV disease burden in nursing home residents, Ellis et al. ${ }^{[31]}$ conducted a population-based analysis of the 
effect of influenza and RSV infections in 81885 nursing home residents in Tennessee, USA. This retrospective cohort study estimated rates of cardiopulmonary hospitalisation, medical care utilisation and death during 4 consecutive years by linking them to viral activity in the general community. On average, RSV accounted for 15 hospitalisations, 76 courses of antibacterials, and 17 deaths per 1000 persons, and for $7 \%$ and $9 \%$ of all cardiopulmonary hospitalisations and deaths, respectively. In contrast, influenza was responsible for 28 hospitalisations and 15 deaths per 1000 persons. Notably, morbidity but not mortality was higher among those with co-morbid conditions.

RSV is also a relatively common cause of illness among frail elderly attending senior daycare programmes. ${ }^{[32]}$ In one 15 -month study, $10 \%$ of 165 elderly attendees developed respiratory infections caused by RSV. This virus, along with influenza and coronaviruses, was among the most commonly identified pathogens.

\subsection{Community-Dwelling Elderly}

A limited number of published studies describe the epidemiology of RSV infection among community dwelling elderly. Data are available from three types of analyses: those describing RSV infection among hospitalised persons with respiratory illness; prospective cohort studies that define infection rates in various elderly or high-risk groups; and statistically derived population-based studies that link respiratory illness rates in large populations to virus activity in the community.

The first report of RSV among older hospitalised patients with pneumonia was from Sweden in 1967. ${ }^{[33]}$ In this report, 18 cases of RSV infection in persons $>55$ years of age, representing $7.4 \%$ of pneumonia cases, were included. A second publication from Sweden encompassing a 10-year period described $57 \mathrm{RSV}$-infected adults with a mean age of 75 years, of whom two-thirds had pneumonia. ${ }^{[34]}$ A more recent 3-year analysis of elderly persons hospitalised during the winter with acute cardiopulmonary symptoms identified RSV serologically in $10 \%$ and influenza in $13 \% .{ }^{[35]}$ Eighteen percent of
RSV-infected persons were admitted to the intensive care unit, $10 \%$ required ventilatory support and $10 \%$ died. Discharge diagnoses included pneumonia in $44 \%$, exacerbation of chronic obstructive pulmonary disease (COPD) in 19\% and congestive heart failure $(\mathrm{CHF})$ in $20 \%$. In a recent report, the same investigators identified $61 \mathrm{RSV}$ infections among 625 persons (10\%) admitted to a large Rochester, NY, USA hospital for acute cardiopulmonary disease. ${ }^{[36]}$ In this study, reverse transcriptase polymerase chain reaction (RT-PCR) assay was used in addition to culture and serology to detect viral aetiology. In another analysis of 1195 adults of all ages admitted to Ohio, USA hospitals with pneumonia, Dowell et al. ${ }^{[37]}$ found that RSV was the third most common aetiology $(4.4 \%)$, behind Streptococcus pneumoniae $(6.2 \%)$ and influenza virus $(5.4 \%)$. Of the $57 \mathrm{RSV}$-infected persons, $68 \%$ were $>64$ years of age. In another study using culture and a virus neutralisation assay, Glezen et al. ${ }^{[38]}$ identified only two RSV infections in 150 hospitalised elderly persons with acute cardiopulmonary syndromes, although interestingly the rate was approximately $4 \%$ among adults 45-64 years of age.

Prospective studies that have assessed the incidence of RSV infection in community-dwelling elderly persons also suggest that this infection is relatively common. ${ }^{[38-41]}$ Despite a steady decline in the overall incidence of respiratory tract infections with advancing age, there is ample evidence that the severity of infection increases. ${ }^{[41]}$ Nicholson et al. ${ }^{[39]}$ noted that $3 \%$ of 497 illnesses in 533 elderly persons followed for 2 years were a result of RSV. This compared with infection rates of $7 \%$ for influenza and $52 \%$ for rhinovirus, but it should be noted that different diagnostic tests were used to detect the three viruses. In another study from the UK, Zambon et al. ${ }^{[41]}$ used a sensitive nested RT-PCR to identify RSV in $15 \%$ of nasopharyngeal swab samples collected from 167 patients $>64$ years of age with acute respiratory illnesses seen by general practitioners over a 3-year period. Influenza was identified in $28 \%$ of the same subjects. These results are similar to our finding that $11 \%$ of 287 winter illnesses in persons $>65$ years of age were a result of RSV 
infection when culture, EIA and RT-PCR were used for diagnosis. ${ }^{[40]}$

Although not limited to elderly subjects, several earlier reports that used culture and serology also described RSV infection in $0-17 \%$ of persons with COPD. ${ }^{[42-51]}$ In one of these studies that spanned 2 years, we documented eight RSV infections in 134 subjects with underlying cardiopulmonary disease (4.3 infections per 100 subject-winters). ${ }^{[36]}$ Illness was significant as three of the eight required hospitalisation. More recently, several investigations have used more sensitive RT-PCR for diagnosis. ${ }^{[52-55]}$ Rohde et al. ${ }^{[53]}$ evaluated the presence of respiratory viruses in 85 subjects with a mean age of 70 years admitted to hospital with acute exacerbations of COPD and in 42 stable COPD patients admitted for other reasons. RSV was detected in $22 \%$ of exacerbations, and in none of the controls. RSV was the third most frequent virus detected after rhinovirus and influenza A virus. Although other investigators have also detected RSV by RT-PCR in patients with COPD exacerbations, they have also noted the equivalent presence of RSV RNA in clinically stable COPD patients. ${ }^{[55]}$ These recent findings raise the possibility that RSV may persist in certain adults, a concept supported by recent observations by Schwarze et al. ${ }^{[56]}$ using a murine model of RSV.

Population-based calculations of the proportion of acute respiratory illnesses attributable to RSV have also provided estimates of disease burden in elderly persons. ${ }^{[6,57,58]}$ In two studies from the UK, RSV was linked to a significant proportion of excess winter time respiratory morbidity, and in one estimate by Nicholson ${ }^{[58]}$ RSV had a greater impact than nonpandemic influenza. ${ }^{[57]}$ Using US healthcare databases and viral surveillance results over a 9-year period, Thompson et al. ${ }^{[6]}$ estimated that RSV infection causes approximately 10000 all-cause deaths annually among persons $>64$ years of age. In contrast, influenza A accounted for approximately 37000 yearly deaths in the same age group. Using similar methods, Griffin et al. ${ }^{[59]}$ estimated that among patients with chronic lung disease in Tennessee, USA, RSV caused 17.7 hospitalisations per 1000 persons and 46.5 deaths per 10000 persons. It should be noted that these results were not calculated using virus-confirmed illnesses but rather were dependent upon several assumptions, including that viral circulation among infants reflects viral activity in elderly populations and that other winter time respiratory viruses do not confound the results.

In all of the studies reported, the highest risk of severe disease from RSV appeared to be persons with underlying chronic medical conditions. In a prospective analysis of RSV infections in elderly adults and those with high-risk conditions (mean age 74 years), we found that the presence of underlying COPD (odds ratio [OR] 3.97; 95\% CI 1.18, 13.37), incremental functional impairment (OR 1.67; 95\% CI 1.23, 2.26) and low neutralising antibody titres (OR 5.89; 95\% CI 1.69, 20.57) were independently associated with severe outcome, defined as hospitalisation during infection. ${ }^{[40]}$

Finally, although relatively infrequent in this age group, elderly persons rendered severely immunocompromised by cytotoxic therapy for acute leukaemia or solid malignancy are at significant risk of fatal outcome during RSV infection. Despite the lack of published studies, it is reasonable to extrapolate the poor outcome seen in younger immunocompromised adults, in which mortality can exceed $90 \%$ with lower respiratory infection, to older persons. ${ }^{[9]}$ The impact of RSV infection among HIV-infected elderly persons is not known, although other than prolonged virus shedding, RSV does not appear to be excessively virulent in younger HIV-infected persons. ${ }^{[60,61]}$

\section{Clinical Manifestations}

Unlike infants in whom RSV produces the readily recognisable syndrome of bronchiolitis, the clinical manifestations of infection with this virus in the elderly are nonspecific and quite variable. Symptoms range from a mild cold-like illness to severe respiratory failure. ${ }^{[62]}$ The full spectrum of disease is best delineated from analysis of prospectively documented infections in senior daycare centres or in outpatient elderly populations. ${ }^{[32,39]}$ In general, the clinical picture is indistinguishable from that of any of the other viral respiratory pathogens, 
with the exception that fever is less pronounced than for influenza. Rhinorrhoea and nasal congestion are seen in the majority, whereas sore throat is reported by about one-quarter of subjects. Similar to influenza infection, cough is nearly universal, being reported by $>90 \%$ of infected subjects. Dyspnoea is reported by $11-20 \%$, whereas gastrointestinal symptoms are extremely uncommon. On examination, the temperature exceeds $38^{\circ} \mathrm{C}$ in half or less of patients. Rales are noted in about one-third of patients and RSV is more apt to be associated with wheezing than is influenza, even in those without underlying obstructive lung disease. Radiographic abnormalities can be seen in patients with lower respiratory signs and symptoms, and are usually unilateral or bilateral patchy subsegmental alveolar infiltrates. ${ }^{[29]}$ However, lobar consolidation was described by Dowell et al. ${ }^{[37]}$ in hospitalised patients with pneumonia as a result of RSV. The role of bacterial superinfection during RSV infection in the elderly is not fully understood. We have noted bacterial pathogens occasionally, and isolated $S$. pneumoniae from the blood from several RSV-infected hospitalised patients (personal observation).

\section{Diagnosis}

Diagnosis of RSV infection in elderly adults is problematic. Whereas in young children RSV results in the distinctive syndrome of bronchiolitis, infection in adults does not produce a characteristic illness distinguishable from other winter time viruses. ${ }^{[30,63]}$ Therefore, diagnosis of RSV requires laboratory confirmation. This may be accomplished by viral culture, detection of viral antigens in respiratory secretions, molecular techniques or serology.

RSV can be detected in a variety of respiratory secretions including nasopharyngeal swabs, nasal washes, sputum or bronchial alveolar lavage fluid. ${ }^{[64-68]}$ Although nasal washes are most commonly used in children, they are poorly tolerated in frail elderly persons and are not practical. Although viral titres may be slightly lower from nasopharyngeal swabs than from nasal washes, nasopharyngeal swabs are an acceptable method of specimen collection in the elderly.
Adults with reinfection shed considerably less virus than infants with primary RSV $\left(\leq 10^{3}\right.$ vs $\sim 10^{6}$ $\mathrm{pfu} / \mathrm{mL}$ ) and shed virus for a shorter duration (3-4 days). ${ }^{[52,64,69,70]}$ The thermolability of RSV compounds the problems of viral isolation. Thus, viral culture that is used successfully in children is insensitive in elderly adults. Culture is approximately $50 \%$ sensitive when performed under ideal circumstances and compared with a highly sensitive serology. In a nursing home study in which transit time of specimens to the laboratory was $<1$ hour, RSV was isolated in $45 \%$ of serologically proven RSV cases. ${ }^{[17]}$ When tissue culture inoculation was performed at the bedside in another study, viral culture performed better and was $67 \%$ sensitive. ${ }^{[65]}$ Unfortunately, in clinical practice, such methodology is not feasible and viral culture is only $20-30 \%$ sensitive compared with serology.

Detection of RSV antigens in nasopharyngeal secretions by immunofluorescence assay (IFA) or EIA obviates the need for viable virus but requires a substantial viral load for adequate detection. These methods are 75-95\% sensitive in young children but are of limited value in adults. ${ }^{[12,71]}$ In a study of 60 older persons with documented RSV, IFA was positive in $23 \%$ and EIA by commercial assay in only $10 \%$ of cases. ${ }^{[12]}$ Given the low prevalence of RSV in older adult populations, the positive predictive value of these tests is very poor, and they cannot be recommended for general use in the elderly. In immunocompromised older persons in whom viral load may be higher, rapid antigen testing may be appropriate. ${ }^{[64]}$

Because of the previously described problems of viral lability and low titres in secretions, new molecular techniques that detect very small amounts of viral RNA by amplification are currently regarded as the optimal method of diagnosis of acute RSV infection. ${ }^{[66,72]}$ RT-PCR has now been used successfully in both paediatric and adult populations. ${ }^{[41,73,74]}$ Primers from the $F$ and $N$ genes of RSV are commonly used and strain-specific RT-PCR can differentiate RSV group A and B viruses. ${ }^{[75,76]}$ In a large study in which 1112 illnesses were evaluated by three methods (viral culture, one-tube nested RT- 
PCR and serology), RT-PCR was $73 \%$ sensitive and 99\% specific, whereas viral culture was 39\% sensitive and $100 \%$ specific. ${ }^{[66]}$ In addition, quantitative RT-PCR has been shown to correlate very well with viral titres calculated by tissue culture in RSV challenge studies. ${ }^{[10]}$ In such experiments, prolonged detection of viral RNA following infection was not found. In addition, detection of RSV RNA in asymptomatic adults even when RSV is prevalent in the community is uncommon. ${ }^{[77]}$

Method of diagnosis becomes an issue not only in clinical care but also when evaluating epidemiological studies. Studies which utilise viral culture and/or antigen detection only are likely to vastly underestimate the incidence of RSV, whereas those employing RT-PCR provide a more accurate assessment of adult disease. For example, a recent Swedish study using culture and IFA identified RSV in $2 \%$ of elderly persons with respiratory illness, whereas $4.8-11 \%$ of illnesses were identified as caused by RSV in a French study using RT-PCR. ${ }^{[72,78]}$ RTPCR is commercially available on a limited basis and is primarily a research tool at the present time.

Various serological methods to detect RSV-specific $\operatorname{IgM}$ and $\operatorname{IgG}$ including complement fixation (CF) and EIA have been used in adults with variable results. A single high-CF titre has been used in a number of studies as indicative of acute RSV infection with some success, but this technique has not been rigorously studied. ${ }^{[18,23,24]}$ When a $\geq 4$-fold rise in titre is required for diagnosis, CF serology is approximately $50 \%$ sensitive when compared with EIA serology using purified viral proteins. ${ }^{[79]}$ In a nursing home study using IgG EIA with purified $\mathrm{F}$ and $\mathrm{G}$ glycoproteins as antigens, $85 \%$ of subjects with culture-confirmed disease demonstrated $\geq$ 4-fold rises in RSV IgG. ${ }^{[17]}$ When using preseason baseline sera, the sensitivity of serology EIA is closer to $90-95 \% .{ }^{[80]}$ Nonetheless, false-negatives may occur, particularly in hospitalised patients in whom acute sera is frequently obtained many days into illness. An interesting yet unexplained observation is that elderly adults have a significantly more vigorous serum antibody response to RSV than healthy young adults. ${ }^{[81]}$ Therefore, serology may actually be a better method for diagnosing RSV in the old than in the young. Although sensitive and specific, serology based on $\operatorname{IgG}$ is limited by the need for convalescent specimens and, thus, diagnosis is retrospective. Serology is primarily a research tool, but it may be useful in outbreak investigations in long-term care facilities.

Detection of $\operatorname{IgM}$ in acute phase sera has been used for the immediate diagnosis of RSV infection but, at present, these assays are not readily available. ${ }^{[37,82,83]} \mathrm{RSV}$-specific IgM was detected in $81 \%$ of RSV-infected hospitalised adults, appearing 6-40 days after the onset of symptoms in one study. ${ }^{[83]} \mathrm{In}$ another study of adult community-acquired pneumonia, RSV IgM was detected in 58\% of confirmed RSV cases. ${ }^{[37]}$ Unfortunately, at the present time, the practising physician is limited to the insensitive techniques of viral culture and antigen detection for the diagnosis of RSV in the elderly adult. Hopefully, RT-PCR will become more widely available in the future.

\section{Treatment}

Treatment of RSV infection in elderly adults is primarily supportive and includes fluids, oxygen and antipyretics. Although use of corticosteroids and bronchodilators in adults with RSV infection has not been examined in controlled studies, their use in the acutely wheezing patient is reasonable. In most instances, patients are not specifically diagnosed with RSV but rather are considered as having asthma or COPD exacerbations. Since a bacterial pathogen will be found in sputum culture in approximately $10-30 \%$ of RSV-infected persons, antibacterials may be prudent in selected patients. ${ }^{[24,34,35,84]}$

Specific antiviral treatment is rarely considered for older adults. This is in part due to the difficulty of rapid diagnosis of acute RSV infection in adults. In addition, the pathogenesis of severe RSV in the elderly is not well understood. It remains a question as to whether or not antivirals will be of benefit since viral load in the nasopharynx is low and patients typically seek medical attention after 5-6 days of illness. The amount of virus in the lower airways of immunocompetent adults has been rarely studied. 
Using quantitative RT-PCR, German investigators found no difference in the titres of RSV in nasal lavage fluid of immunocompetent adults compared with induced sputum in COPD patients; however, respiratory viruses were more often detected in sputum. ${ }^{[52]}$ Nonetheless, it may be reasonable to consider antiviral treatment in selected patients who present early with severe disease in whom a specific diagnosis of RSV infection has been made. Preemptive therapy may also be considered in high-risk patients or patients who are immunocompromised since a high percentage of these patients will develop serious lower respiratory tract disease. ${ }^{[85-87]}$

At the present time, aserosolised ribavirin is the only licensed antiviral for the treatment of RSV. ${ }^{[88,89]}$ Ribavirin is a guanosine analogue and inhibits the replication of a wide range of viruses, including RSV. A number of other anti-RSV agents, such as fusion inhibitors and antisense molecules, are currently in development. ${ }^{[90-92]}$ Ribavirin is approved for use in infants although its use is somewhat controversial. Placebo-controlled, randomised trials have not always shown clear benefit although most show a beneficial trend. ${ }^{[93-95]}$ In addition to ribavirin, two immunoglobulin preparations (polyclonal high-titred RSV IgG and a humanised Fspecific monoclonal antibody) are approved for prophylactic use in high-risk children.$^{[96-99]}$ Data on the use of ribavirin and immunoglobulin in adults derived primarily from small, uncontrolled studies and anecdotal reports of treatment of the elderly do not provide enough data to make general recommendations. ${ }^{[100-103]}$ In one report, one of two adult patients with nosocomial RSV died despite treatment with ribavirin. ${ }^{[101]}$ The safety of aerosolised ribavirin was evaluated in eight uninfected elderly volunteers and treatment was well tolerated, even in those with COPD. ${ }^{[104]}$ It may be difficult to administer ribavirin by face mask for the prolonged recommended periods ( $20 \mathrm{mg} / \mathrm{mL}$ for 18 hours a day) in confused older patients. Therefore, high-dose, short-duration therapy $(60 \mathrm{mg} / \mathrm{mL}$ for 2 hours three times daily) is an alternative and may be better tolerated. ${ }^{[105]}$

Immunocompromised patients with lower respiratory symptoms should always be considered for antiviral treatment since mortality rates are very high. Although much of the data on the use of ribavirin and immunoglobulin comes from patients with bone marrow transplants, an uncommon procedure in the elderly, these results can be generalised to other conditions, such as leukaemia, lymphoma and immunosuppression secondary to chemotherapy for solid tumours. The use of aserosolised ribavirin alone to treat RSV pneumonia in bone marrow transplant recipients was not associated with significantly different mortality to the $70 \%$ rate observed in historical controls. ${ }^{[106,107]}$ However, when combined with high-titred RSV immunoglobulin, mortality decreased to $50 \% .{ }^{[86]}$ Initiation of treatment prior to the onset of respiratory failure is considered to be critical to success. ${ }^{[103]}$

\section{Prevention}

RSV is believed to be transmitted primarily by large droplets and fomites. ${ }^{[108,109]}$ Thus, close person-to-person contact or contact with contaminated environmental surfaces and autoinoculation are necessary for transmission. ${ }^{[70,110]}$ Unlike influenza, which spreads efficiently via small particle aerosols and causes explosive outbreaks in nursing homes, RSV tends to spread slowly with a steady trickle of cases. ${ }^{[20]}$ Various infection control strategies, principally hand washing, have been employed to limit nosocomial spread of RSV. ${ }^{[111]}$ Since compliance with hand washing is frequently poor, use of gowns and gloves has been advocated in paediatric wards. ${ }^{[112]}$ Masks are not necessary but cohorting and isolation of infected patients is desirable if possible. Education of staff regarding transmission of respiratory viruses and the value of hand washing was associated with a significant decrease in rates of acute respiratory tract infections in adult daycare centres. ${ }^{[113]}$

Immunisation may provide the best option for prevention of severe RSV disease in elderly and high-risk adults. Low serum neutralisation antibody has been demonstrated to be a risk factor for both infection and severe disease. ${ }^{[40,114]}$ Unfortunately, at the present time, there is no licensed RSV vaccine although several candidate vaccines are in develop- 
ment. Immunisation with a purified $\mathrm{F}$ protein subunit vaccine was successful in inducing a 4-fold rise in antibody in $61 \%$ of healthy elderly and $47 \%$ of institutionalised elderly vaccine recipients. ${ }^{[115,116]}$ However, the immunogenicity of a live attenuated RSV vaccine was poor in healthy elderly persons, presumably because of low infection rates. ${ }^{[117]}$

\section{Conclusion}

Since RSV was first described as a serious pathogen in young children approximately 50 years ago there has been growing evidence that it is a common cause of illness in adults and is associated with substantial morbidity in elderly and frail adults. RSV is second only to influenza as a cause of serious viral respiratory disease. Because of its nondistinctive clinical syndrome and difficulties with diagnosis, the virus remains a largely unrecognised cause of illness in elderly persons by internists and family practitioners. Continued research on therapy and methods of prevention are needed to reduce the substantive burden of RSV disease in the elderly.

\section{Acknowledgements}

No sources of funding were used to assist in the preparation of this review. The authors have no conflicts of interest that are directly relevant to the content of this review.

\section{References}

1. Collins P. The molecular biology of human respiratory syncytial viruses (RSV) of the genus Pneumovirus. In: Kingsbury DW, editor. The Paramyxoviruses. New York: Plenum Publishing, 1991: 103-62

2. Anderson LJ, Hierholzer JC, Tsou C, et al. Antigenic characterizaton of respiratory syncytial virus strains with monoclonal antibodies. J Infect Dis 1985; 151: 626-33

3. Hendry RM, Talis AL, Godfrey E, et al. Concurrent circulation of antigenically distinct strains of respiratory syncytial virus during community outbreaks. J Infect Dis 1986; 153: 291-7

4. Hendry RM, Fernie BF, Anderson LJ, et al. Antigenic and epidemiologic analysis of distinct strains of respiratory syncytial virus from two successive community outbreaks [1983-85]. In: Mahy B, Kolakofsky D, editors. Biology of negative strand viruses. Amsterdam: Elsevier Science Publishers BV, 1987: 397-403

5. van den Hoogen BG, De Jong JC, Groen J, et al. A newly discovered human pneumovirus isolated from young children with respiratory tract disease. Nat Med 2001; 7: 719-24

6. Thompson WW, Shay DK, Weintraub E, et al. Mortality associated with influenza and respiratory syncytial virus in the United States. JAMA 2003; 289: 179-86
7. Hall CB. Respiratory syncytial virus and parainfluenza virus. N Engl J Med 2001; 334: 1917-28

8. Falsey AR, Walsh EE. Respiratory syncytial virus infection in adults. Clin Microbiol Rev 2000; 13: 371-84

9. Englund JA, Sullivan CJ, Jordan MC, et al. Respiratory syncytial virus infection in immunocompromised adults. Ann Intern Med 1988; 109: 203-8

10. Falsey AR, Formica MA, Treanor JJ, et al. Comparison of quantitative reverse transcription-PCR to viral culture for assessment of respiratory syncytial virus shedding. J Clin Microbiol 2003; 41: 4160-5

11. Hall CB, Geiman JM, Biggar R, et al. Respiratory syncytial virus infections within families. N Engl J Med 1976; 294 : 414-9

12. Casiano-Colon AE, Hulbert BB, Mayer TK, et al. Lack of sensitivity of rapid antigen tests for the diagnosis of respiratory syncytial infection in adults. J Clin Virol 2003; 28: 169-74

13. Agius G, Dindinaud G, Biggar RJ, et al. An epidemic of respiratory syncytial virus in elderly people: clinical and serological findings. J Med Virol 1990; 30: 117-27

14. Arroyo JC, Jordan W, Milligan L. Upper respiratory tract infection and serum antibody responses in nursing home patients. Am J Infect Control 1988; 16: 152-8

15. Center for Disease Control. Epidemiologic notes and reports. Respiratory syncytial virus: Missouri. MMWR Morb Mortal Wkly Rep 1977; 26: 351

16. Falsey AR, Walsh EE, Betts RF. Serologic evidence of respiratory syncytial virus infection in nursing home patients. J Infect Dis 1990; 162: 568-9

17. Falsey AR, Treanor JJ, Betts RF, et al. Viral respiratory infections in the institutionalized elderly: clinical and epidemiologic findings. J Am Geriatr Soc 1992; 40: 115-9

18. Garvie DG, Gray J. Outbreak of respiratory syncytial virus infection in the elderly. BMJ 1980; 281: 1253-4

19. Gross PA, Rodstein M, LaMontagne JR, et al. Epidemiology of acute respiratory illness during an influenza outbreak in a nursing home. Arch Intern Med 1988; 148: 559-61

20. Hart RJC. An outbreak of respiratory syncytial virus infection in an old people's home. J Infect 1984; 8: 259-61

21. Hornsleth A, Siggaard-Andersen J, Hjort L. Epidemiology of herpesvirus and respiratory virus infections. Part 1: serologic findings. Geriatrics 1975; 30: 61-8

22. Mandal SK, Joglekar VM, Khan AS. An outbreak of respiratory syncytial virus infection in a continuing-care geriatric ward. Age Ageing 1985; 14: 184-6

23. Mathur U, Bentley DW, Hall CB. Concurrent respiratory syncytial virus and influenza A infections in the institutionalized elderly and chronically ill. Ann Intern Med 1980; 93: 49-52

24. Morales F, Calder MA, Inglis JM, et al. A study of respiratory infection in the elderly to assess the role of respiratory syncytial virus. J Infect 1983; 7: 236-47

25. Nicholson KG, Baker DJ, Farquhar A, et al. Acute upper respiratory tract viral illness and influenza immunization in homes for the elderly. Epidemiol Infect 1990; 105: 609-18

26. Orr PH, Peeling RW, Fast M, et al. Serological study of responses to selected pathogens causing respiratory tract infection in the institutionalized elderly. Clin Infect Dis 1996; 23: 1240-5

27. Osterweil D, Norman D. An outbreak of an influenza-like illness in a nursing home. J Am Geriatr Soc 1990; 38: 659-62

28. Public Health Laboratory Service Communicable Diseases Surveillance Centre. Respiratory syncytial virus infection in the elderly 1976-1982. BMJ 1983; 287: 1618-9 
29. Sorvillo FJ, Huie SF, Strassburg MA, et al. An outbreak of respiratory syncytial virus pneumonia in a nursing home for the elderly. J Infect 1984; 9: 252-6

30. Wald TG, Miller BA, Shult P, et al. Can respiratory syncytial virus and influenza $\mathrm{A}$ be distinguished clinically in institutionalized older persons? J Am Geriatr Soc 1995; 43: 170-4

31. Ellis SE, Coffey CS, Mitchel Jr EF, et al. Influenza- and respiratory syncytial virus-associated morbidity and mortality in the nursing home population. J Am Geriatr Soc 2003; 51: 761-7

32. Falsey AR, McCann RM, Hall WJ, et al. Acute respiratory tract infection in daycare centers for older persons. J Am Geriatr Soc 1995; 43: 30-6

33. Fransen $\mathrm{H}$, Heigl Z, Wolontis $\mathrm{S}$, et al. Infections with viruses in patients hospitalized with acute respiratory illness, Stockholm 1963-1967. Scand J Infect Dis 1969; 1: 127-36

34. Vikerfors T, Grandien M, Olcen P. Respiratory syncytial virus infections in adults. Am Rev Respir Dis 1987; 136: 561-4

35. Falsey AR, Cunningham CK, Barker WH, et al. Respiratory syncytial virus and influenza A infections in the hospitalized elderly. J Infect Dis 1995; 172: 389-94

36. Walsh EE, Falsey AR, Hennessey PA. Respiratory syncytial virus and other infections in persons with chronic cardiopulmonary disease. Am J Respir Crit Care Med 1999; 160: 791-5

37. Dowell SF, Anderson LJ, Gary Jr HE, et al. Respiratory syncytial virus is an important cause of community-acquired lower respiratory infection among hospitalized adults. J Infect Dis 1996; 174: 456-62

38. Glezen WP, Greenberg SB, Atmar RL, et al. Impact of respiratory virus infections on persons with chronic underlying conditions. JAMA 2000; 283: 499-505

39. Nicholson KG, Kent J, Hammersley V, et al. Acute viral infections of upper respiratory tract in elderly people living in the community; comparative, prospective, population based study of disease burden. BMJ 1997; 315: 1060-4

40. Walsh EE, Peterson DR, Falsey AR. Risk factors for severe respiratory syncytial virus infection in elderly adults. J Infect Dis 2004; 189: 233-8

41. Zambon MC, Stockton JD, Clewley JP, et al. Contribution of influenza and respiratory syncytial virus to community cases of influenza-like illness: an observational study. Lancet 2001; 358: $1410-6$

42. Buscho RO, Saxtan D, Shultz PS, et al. Infections with viruses and Mycoplasma pneumoniae during exacerbations of chronic bronchitis. J Infect Dis 1978; 137: 377-83

43. Carilli AP, Gohd R, Gordon W. A virologic study of chronic bronchitis. N Engl J Med 1964; 170: 123-7

44. Fagon JY, Chastre J. Severe exacerbations of COPD patients: the role of pulmonary infections. Semin Respir Infect 1996; 11: $109-18$

45. Gump DW, Phillips CA, Forsyth BR. Role of infection in chronic bronchitis. Am Rev Respir Dis 1976; 113: 465-74

46. Lambert HP, Stern H. Infective factors in exacerbations of bronchitis and asthma. BMJ 1972; 3: 323-7

47. Lamy ME, Pouthier-Simon F, Debacker-Willame E. Respiratory viral infections in hospital patients with chronic bronchitis: observations during periods of exacerbation and quiescence. Chest 1973; 63: 336-41

48. Smith CB, Golden CA, Kanner RE, et al. Association of viral and Mycoplasma pneumoniae infections with acute respiratory illness in patients with chronic obstructive pulmonary diseases. Am Rev Respir Dis 1980; 121: 225-32
49. Sommerville RG. Respiratory syncytial virus in acute exacerbations of chronic bronchitis. Lancet 1963; II: $1247-8$

50. Stenhouse AC. Viral antibody levels and clinical status in acute exacerbations of chronic bronchitis: a controlled prospective study. BMJ 1968; 3: 287-90

51. Wiselka MJ, Kent J, Cookson JB, et al. Impact of respiratory infection in patients with chronic chest disease. Epidemiol Infect 1993; 111: 337-46

52. Borg I, Rohde G, Loseke S, et al. Evaluation of quantitative realtime PCR for the detection of respiratory syncytial virus in pulmonary diseases. Eur Respir J 2003; 21: 944-51

53. Rohde G, Wiethege A, Borg I, et al. Respiratory viruses in exacerbations of chronic obstructive pulmonary disease requiring hospitalisation: a case-control study. Thorax 2003; 58: 37-42

54. Seemungal TAR, Wedzicha JA. Viral infections in obstructive airway diseases. Curr Opin Pulm Med 2003; 9: 111-6

55. Seemungal T, Harper-Owen R, Bhowmik A, et al. Respiratory viruses, symptoms, and inflammatory markers in acute exacerbations and stable chronic obstructive pulmonary disease. Am J Respir Crit Care Med 2001; 164: 1618-23

56. Schwarze J, O'Donnell DR, Rohwedder A, et al. Latency and persistence of respiratory syncytial virus despite $\mathrm{T}$ cell immunity. Am J Respir Crit Care Med 2004; 169: 801-5

57. Fleming DM, Cross KW. Respiratory syncytial virus or influenza? Lancet 1993; 342: 1507-10

58. Nicholson KG. Impact of influenza and respiratory syncytial virus on mortality in England and Wales from January 1975 to December 1990. Epidemiol Infect 1996; 116: 51-63

59. Griffin M, Coffey CS, Neuzil KM, et al. Winter viruses: influen$\mathrm{za}$ and respiratory syncytial virus-related morbidity in chronic lung disease. Arch Intern Med 2003; 162: 1229-36

60. Murphy D, Rose RC. Letters: respiratory syncytial viral pneumonia in a human immunodeficiency virus-infected man. JAMA 1989; 261: 1147

61. Sriskandan S, Shaunak S. Correspondence: respiratory syncytial infection in an adult with AIDS. Clin Infect Dis 1993; 17: 1065

62. Falsey AR. Respiratory syncytial virus infection in older persons. Vaccine 1998; 16: 1775-8

63. Falsey AR, Erdman D, Anderson LJ, et al. Human metapneumovirus infections in young and elderly adults. J Infect Dis 2003; 187: 785-90

64. Englund JA, Piedra P, Jewell A, et al. Rapid diagnosis of respiratory syncytial virus infections in immunocompromised adults. J Clin Microbiol 1996; 34: 1649-53

65. Falsey AR, McCann RM, Hall WJ, et al. Evaluation of four methods for the diagnosis of respiratory syncytial virus infection in older adults. J Am Geriatr Soc 1996; 44: 71-3

66. Falsey AR, Formica MA, Walsh EE. Diagnosis of respiratory syncytial virus infection: comparison of reverse transcriptionPCR to viral culture and serology in adults with respiratory illness. J Clin Microbiol 2002; 40: 817-20

67. Kimball AM, Foy HM, Cooney MK, et al. Isolation of respiratory syncytial and influenza viruses from the sputum of patients hospitalized with pneumonia. J Infect Dis 1983; 147: 181-4

68. Simpson JL, Moric I, Wark P, et al. Use of induced sputum for the diagnosis of influenza and infections in asthma: a comparison of diagnostic methods. J Clin Virol 2003; 26: 339-46

69. Hall CB, Douglas RG, Geiman JM. Respiratory syncytial virus infections in infants: quantitation and duration of shedding. $\mathrm{J}$ Pediatr 1976; 131: 1-5

70. Hall CB, Douglas RG, Geiman JM, et al. Nosocomial respiratory syncytial virus infections. N Engl J Med 1975; 293: 1343-6 
71. Kellogg JA. Culture vs direct antigen assays for detection of microbial pathogens from lower respiratory tract specimens suspected of containing the respiratory syncytial virus. Arch Pathol Lab Med 1991; 115: 451-8

72. Freymuth F, Vabret A, Gouarin S, et al. Epidemiology and diagnosis of respiratory syncytial virus in adults. Rev Mal Respir 2004; 21: 13-4

73. Henkel JH, Aberle SW, Kundi M, et al. Improved detection of respiratory syncytial virus in nasal aspirates by seminested RTPCR. J Med Virol 1997; 53: 366-71

74. van Milaan AJ, Sprenger MJW, Rothbarth PH, et al. Detection of respiratory syncytial virus by RNA-polymerase chain reaction and differentiation of subgroups with oligonucleotide probes. J Med Virol 1994; 44: 80-7

75. Fan J, Henrickson KJ, Savatski LL. Rapid simultaneous diagnosis of infections with respiratory syncytial viruses A and B, influenza viruses $\mathrm{A}$ and $\mathrm{B}$, and human parainfluenza virus types 1,2 , and 3 by multiplex quantitative reverse transcription: polymerase chain reaction-enzyme hybridization [hexaplex] assay. Clin Infect Dis 1998; 26: 1-6

76. Stockton J, Ellis JS, Saville M, et al. Multiplex PCR for typing and subtyping influenza and respiratory syncytial viruses. J Clin Microbiol 1998; 36: 2990-5

77. Falsey AR, Criddle MC, Walsh EE. Detection of respiratory syncytial virus and human metapneumovirus by reverse transcription polymerase chain reaction in adults with and without respiratory illness. J Clin Virol. In press

78. Ostlund MR, Wirgart BZ, Linde A, et al. Respiratory virus infections in Stockholm during seven seasons: a retrospective study of laboratory diagnosis. Scand J Infect Dis 2004; 36: 460-5

79. Marrie TJ, Falsey AR, Campbell NN, et al. The complement fixation test is not sensitive for the diagnosis of respiratory syncytial virus in patients with community acquired pneumonia (CAP) [abstract]. 41st Interscience Conference on Antimicrobial Agents and Chemotherapy; 2001 Dec 16-19; Chicago (IL)

80. Falsey AR, Hennessey PA, Formica MA, et al. Respiratory syncytial virus infection in elderly and high-risk adults. N Engl J Med 2005; 352 (17): 1749-59

81. Walsh EE, Falsey AR. Age related differences in humoral immune response to respiratory syncytial virus infection in adults. J Med Virol 2004; 73: 295-9

82. Erdman D, Anderson LJ. Monoclonal antibody-based capture enzyme immunoassays for specific serum immunoglobulin $\mathrm{G}$ [IgG], IgA, and IgM antibodies to respiratory syncytial virus. J Clin Microbiol 1990; 28: 2744-9

83. Vikerfors T, Grandien M, Johansson M, et al. Detection of an immunoglobulin $\mathrm{M}$ response in the elderly for early diagnosis of respiratory syncytial virus infection. J Clin Microbiol 1988; 26: $808-11$

84. Zaroukian MH, Leader I. Community-acquired pneumonia and infection with respiratory syncytial virus. Ann Intern Med 1988; 109: 515-6

85. Whimbey E, Couch RB, Englund JA, et al. Respiratory syncytial virus pneumonia in hospitalized adult patients with leukemia. Clin Infect Dis 1995; 21: 376-9

86. Whimbey E, Champlin RE, Couch RB, et al. Community respiratory virus infections among hospitalized adult bone marrow transplant recipients. Clin Infect Dis 1996; 22: 778-82

87. Whimbey E, Englund JA, Couch RB. Community respiratory virus infections in immunocompromised patients with cancer. Am J Med 1997; 102: 10-8
88. Committee on Infectious Diseases. Use of ribavirin in the treatment of respiratory syncytial virus infection. Pediatrics 1993; 92: 501-4

89. Committee on Infectious Diseases. Reassessment of the indications for ribavirin therapy in respiratory syncytial virus infections. Pediatrics 1996; 97: 137-40

90. Cianci C, Kuo-long Y, Combrink K, et al. Orally active fusion inhibitor of respiratory syncytial virus. Antimicrob Agents Chemother 2004; 48: 413-22

91. Gazumyan A, Mitsner B, Ellestad GA. Novel anti-RSV dianionic dendrimer-like compounds: Synthesis and Biological Evaluation. Curr Pharm Des 2000; 6: 525-46

92. Maggon K, Barik S. New drugs and treatment for respiratory syncytial virus. Rev Med Virol 2004; 14: 149-68

93. Hall CB, McBride JT, Gala CL, et al. Ribavirin treatment of respiratory syncytial viral infection in infants with underlying cardiopulmonary disease. JAMA 1985; 254: 3047-51

94. Hall CB, McBride JT, Walsh EE, et al. Aerosolized ribavirin treatment of infants with respiratory syncytial viral infection. N Engl J Med 1983; 308: 1443-7

95. Rodriguez WJ, Arrobio J, Fink R, et al. Prospective follow-up and pulmonary functions from a placebo-controlled randomized trial of ribavirin therapy in respiratory syncytial virus bronchiolitis. Arch Pediatr Adolesc Med 1999; 153: 469-74

96. Groothuis JR, Simoes EAF, Levin MJ, et al. Prophylactic administration of respiratory syncytial virus immune globulin to high-risk infants and young children. N Engl J Med 1993; 329: 1524-30

97. Groothuis JR, Simoes EAF, Hemming VG, et al. Respiratory syncytial virus [RSV] infection in preterm infants and the protective effects of RSV immune globulin [RSVIG]. Pediatrics 1995; 95: 463-7

98. Rodriguez WJ, Gruber WC, Welliver RC, et al. Respiratory syncytial virus [RSV] immune globulin intravenous therapy for RSV lower respiratory tract infection in infants and young children at high risk for severe RSV infections: Respiratory Syncytial Virus Immune Globulin Study Group. Pediatrics 1997; 99: 472-5

99. Sorrentino M, Powers T. Effectiveness of palivizumab: evaluation of outcomes from the 1998 to 1999 respiratory syncytial virus season. Palivizumab Outcomes Study Group. Pediatr Infect Dis J 2000; 19: 1068-71

100. Englund JA, Piedra PA, Whimbey E. Prevention and treatment of respiratory syncytial virus and parainfluenza viruses in immunocompromised patients. Am J Med 1997; 102: 61-70

101. Feldman RJ, Fidalgo HC, John Jr JF. Respiratory syncytial virus in a cardiac surgery intensive care unit [letter]. J Thorac Cardiovasc Surg 1994; 108: 1152

102. Takimoto CH, Cram DL, Root RK. Respiratory syncytial virus infections on an adult medical ward. Arch Intern Med 1991; 151: 706-8

103. Whimbey E, Champlin RE, Englund JA, et al. Combination therapy with aerosolized ribavirin and intravenous immunoglobulin for respiratory syncytial virus disease in adult bone marrow transplant recipients. Bone Marrow Transplant 1995; 16: $393-9$

104. Liss HP, Bernstein J. Ribavirin aerosol in the elderly. Chest 1988; 93: 1239-41

105. Englund JA, Piedra P, Jefferson LS, et al. High-dose, short duration ribavirin aerosol therapy in children with suspected respiratory syncytial virus infection. J Pediatr 1990; 117: 313-20 
106. Harrington RD, Hooton TM, Hackman RC, et al. An outbreak of respiratory syncytial virus in a bone marrow transplant center. J Infect Dis 1992; 165: 987-93

107. Hertz MI, Englund JA, Snover D, et al. Respiratory syncytial virus-induced acute lung injury in adult patients with bone marrow transplants: a clinical approach and review of the literature. Medicine (Baltimore) 1989; 68: 269-81

108. Hall CB, Douglas RG, Geiman JM. Possible transmission by fomites of respiratory syncytial virus. J Infect Dis 1980; 141: 98-102

109. Hall CB, Douglas Jr RG. Modes of transmission of respiratory syncytial virus. J Pediatr 1981; 99: 100-3

110. Rechsteiner J, Winkler KC. Inactivation of respiratory syncytial virus in aerosol. J Gen Virol 1969; 5: 405-10

111. Madge P, Paton JY, McColl JH, et al. Prospective controlled study of four infection-control procedures to prevent nosocomial infection with respiratory syncytial virus. Lancet 1992; 340: 1079-83

112. Graman PS, Hall CB. Epidemiology and control of nosocomial viral infections. Infect Dis Clin N Am 1989; 3: 815-41

113. Falsey AR, Criddle MM, Kolassa JE, et al. Evaluation of a handwashing intervention to reduce respiratory illness rates in senior day-care centers. Infect Control Hosp Epidemiol 1999; 20: $200-2$

114. Walsh EE, Falsey AR. Humoral and mucosal immunity in protection from natural respiratory syncytial virus infection in adults. J Infect Dis 2004; 190: 373-8

115. Falsey AR, Walsh EE. Safety and immunogenicity of a respiratory syncytial virus subunit vaccine [PFP-2] in ambulatory adults over age 60. Vaccine 1996; 14: 1214-8

116. Falsey AR, Walsh EE. Safety and immunogenicity of a respiratory syncytial virus subunit vaccine [PFP-2] in the institutionalized elderly. Vaccine 1997; 15: 1130-2

117. Gonzalez IM, Karron RA, Eichelberger M, et al. Evaluation of the live attenuated cpts 248/404 RSV vaccine in combination with a subunit RSV vaccine [PFP-2] in healthy young and older adults. Vaccine 2000; 18: 1763-72

Correspondence and offprints: Dr Ann R. Falsey, Rochester General Hospital, 1425 Portland Ave, Rochester, NY 14621, USA.

E-mail: ann.falsey@viahealth.org 